\title{
Determination of protein and reactive lysine in leaf-protein concentrates by dye-binding
}

\author{
BY ANN F. WALKER \\ Department of Food Science, University of Reading, London Road, Reading RGI $5 A Q$
}

(Received I5 February 1979 - Accepted 30 April 1979)

1. Twenty leaf-protein concentrates (LPC), were produced from different crops and by different processes, the latter being designed to retain maximum nutritional value of the samples.

2. The establishment of conditions for the use of CI Acid Orange 12 in a commercial dye-buffer reagent for the determination of protein and reactive (available) lysine in LPC was investigated.

3. Values for protein by dye-binding correlated well with those for tungstic-acid-precipitated nitrogen $(\times 6 \cdot 25)$.

4. Some LPC samples showed a loss of reactive lysine, the greatest loss being associated with the most severe processing conditions.

5. For the LPC samples studied, dye-binding provided a convenient method for the concurrent determination of protein and reactive lysine.

Dye-binding methods for the determination of protein are widely used for some foodstuffs, but the method must be established for each foodstuff by relating it to the nitrogen content as determined by Kjeldahl digestion (Lakin, 1973). Dye-binding, using acid dyes at low pH, primarily involves the formation of ionic linkages with the basic amino acids (lysine, histidine and arginine) present in protein, as well as with terminal amino groups.

More recently, dye-binding methods have been modified to estimate reactive (available) lysine in foodstuffs. As lysine is usually the first amino acid to be affected by processing conditions (Carpenter, 1974), a simple method for its determination would be of use in monitoring nutritional change. During the production of leaf-protein concentrate (LPC), opportunities exist for these changes to take place (Allison et al. 1973); in addition to the possibilities of Maillard damage, loss of reactive lysine may be due to polyphenol-protein interaction in such materials (Pierpoint, 1969a,b).

The dye-binding method for determining reactive lysine involves blocking the $\varepsilon$-amino group, various reagents having been used to do this, e.g. ethyl chloroformate (Sandler \& Warren, 1974) and trinitrobenzenesulphonic acid (Jones, 1974). A modification of the propionylation method of Hurrell \& Carpenter (I976) is described in this paper. Reactive lysine was calculated as the difference between that determined by dye-binding before and after propionylation (dye-binding lysine; DBL). The rapidity of this method contrasts with other chemical methods for determining reactive lysine in foodstuffs, which are laborious and complex (Carpenter \& Booth, 1973).

Dye-binding methods for protein determination are particularly suitable for foodstuffs that show little variation in amino acid pattern, i.e. where the proportion of basic amino acids in the protein can be assumed to be constant. Leaf proteins exhibit constancy of amino acid pattern (Gerloff et al. 1965; Byers, 1971 a). Apart from proline (where ionexchange chromatography information is not very precise), the greatest variation of amino acids between LPC samples lies in total lysine content (Byers, I97 I $a$ ). On the contrary, the DBL value should be independent of the amino acid pattern.

The DBL value has been determined for twenty LPC samples, some of which were prepared by processes designed to retain maximum nutritional value. Values for the dye-binding 
Table I. Details of leaf-protein concentrate (LPC) samples used

Leaf source

Lucerne (Medicago sativa L.)
Type of

Sample pulper and

no. press used

\begin{tabular}{|c|c|c|}
\hline I & A & \\
\hline 2 & B & \\
\hline 3 & B & \\
\hline 4 & A & \\
\hline 5 & $\mathbf{B}$ & \\
\hline 6 & B & $\begin{array}{l}\text { Precipitated by steam at } 75^{\circ} \text {; same juice } \\
\text { batch as lucerne sample no. } 3\end{array}$ \\
\hline 7 & B & $\begin{array}{l}\text { Precipitated by steam at } 95^{\circ} \text {; same } \\
\text { juice batch as lucerne sample no. } 3\end{array}$ \\
\hline 8 & A & $\begin{array}{l}\text { Produced in Coimbatore, India, by steam } \\
\text { to } 90^{\circ} \text {. Curd acidified to } \mathrm{pH} 4.5 \text {. Dried } \\
\text { in hot air } 40-60^{\circ}\end{array}$ \\
\hline & $\begin{array}{l}\text { Twin } \\
\text { screw press }\end{array}$ & $\begin{array}{l}\text { Commercial feed; Dengie Crop Dryers } \\
\text { (Wilsdon, 1977) }\end{array}$ \\
\hline & B & LCP blackened during freeze-drying \\
\hline
\end{tabular}

Ryegrass (Italian)

(Lolium multiflorum L. var. RVP)

Fescue

(Festuca arundinacea L. var. Alta)

Kale (Brassica oleracea L.)

Quinoa (Chenopodium quinoa L.)

Fat hen (Chenopodium album L.)

A, laboratory-scale pulper and press; B, large-scale pulper and press; C, Bentalls 'Protessor' screw press.

capacity (DBC) were compared with those for protein content (tungstic-acid-precipitated $\mathrm{N} \times 6 \cdot 25$ ). The use of the Foss FHI-I dye-buffer reagent without specially designed equipment is described and the reaction conditions for dye-binding were chosen so that the uptake of $\mathrm{CI}$ Acid Orange $\mathrm{I} 2$ reached equilibrium.

EXPERIMENTAL

Preparation of LPC samples

The LPC samples are described in detail in Table I. They were prepared during the 1975 and 1976 seasons by processes designed to cause the least nutritional damage. Most samples were produced as follows.

The crop was harvested, chopped, and then pulped and pressed within I h. Samples were processed using either a laboratory-scale pulper and beam press (Davys \& Pirie, I $969 a, b$ ), a large-scale pulper and belt press (Davys \& Pirie, 1960, I965) or a screw press (Bentalls 'Protessa' screw press; E. H. Bentalls and Co. Ltd, Maldon, Essex). The juice obtained was centrifuged as soon as possible (if necessary it was stored at $4^{\circ}$ for a period not exceeding $2 \mathrm{~h}$ ) at $1900 \mathrm{~g}$ for $15 \mathrm{~min}$ at $4^{\circ}$ to separate cell debris, and passed through a $53 \mu \mathrm{m}$ sieve to remove fibre. Protein was coagulated by injecting steam to increase the temperature rapidly to $85^{\circ}$ and removed while hot by filtering through cheesecloth. Batches 
of $1-41$ of the leaf juice were treated in this way. The coagulum was drained, washed with a quantity of tap water equal to twice the original volume of juice, drained again and pressed to approximately $500 \mathrm{~g}$ moisture $/ \mathrm{kg}$ in a hand-operated hydraulic press. It was dried overnight in a Vickers freeze-drier (Vickers-Armstrong (South Marston) Ltd, South Marston Works, Swindon) using a shelf heat of $30^{\circ}$. Samples were allowed to equilibrate in air for approximately $8 \mathrm{~h}$ and then ground in a Cyclone Sample Mill with a fine sieve attachment (Tecator Ltd, 7I Whiteladies Road, Bristol BS8 $2 \mathrm{NT}$ ). After this treatment all the material passed a $183 \mu \mathrm{m}$ screen; $750 \mathrm{~g} / \mathrm{kg}$ passed a $1 \mathrm{I} 2 \mu \mathrm{m}$ screen. Particle size was determined using a Model Laboratory Plensifter (Thomas Robinson and Son Ltd, Rochdale, Lancs).

\section{Analysis of LPC samples}

$D B C$ determination. LPC samples $(0.08-0.12 \mathrm{~g})$ were weighed into $100 \mathrm{ml}$ polyethylene bottles and three $6 \mathrm{~mm}$ glass beads and $2 \mathrm{ml} \mathrm{2.2} \mathrm{M-sodium} \mathrm{acetate} \mathrm{were} \mathrm{added} \mathrm{to} \mathrm{each} \mathrm{and}$ mixed well. Foss FHI-I dye-buffer reagent $(40 \mathrm{ml})$ was added. This reagent was devised by Foss Electric (UK) Ltd, The Chantry, Bishopthorpe, York YO2 IQF, for use in their Pro-Meter Mark II. It contains $3.89 \mathrm{mmol}$ CI Acid Orange I2/l, $200 \mathrm{~g}$ oxalic acid dihydrate, $34 \mathrm{~g}$ potassium dihydrogen phosphate, $600 \mathrm{ml}$ glacial acetic acid and water to $10 \mathrm{l}$. The bottles were stoppered and shaken at $25^{\circ}$ overnight. The mixture was filtered (Whatman $\mathrm{GF} / \mathrm{A}$ ) and approximately $10 \mathrm{ml}$ filtrate collected.

A standard dye solution was prepared, containing approximately $2 \cdot 7 \mathrm{mmol}$ recrystallized CI Acid Orange I2/l water; this can be stored in the dark at room temperature for several months. This standard solution was diluted with water to give an absorbance at $482 \mathrm{~nm}$ of 0.7 (against a water blank), and the spectrophotometer (SP 500 series 2; Pye Unicam) adjusted to read directly the concentration of the standard. The sample filtrates were diluted to the same extent (an arbitrary dilution) with water, as was the reagent blank. The latter consisted of $40 \mathrm{ml}$ Foss FHI-I dye-buffer $+2 \mathrm{ml} 2 \cdot 2 \mathrm{M}$-sodium acetate, mixed and diluted $I: I(v / v)$ with water to bring it within the same absorbance range as the sample filtrates. Distilled water was used as a blank for all measurements and each sample filtrate, standard and reagent blank was measured in triplicate. The standard was included at the beginning and end of each cycle of the automatic sampler so that correction could be made for any drift in the machine.

Calculations were made as follows.

The concentrations of the reagent blank and filtrate were calculated from the concentration of the standard and corrected for machine drift by multiplying by the factor:

$$
\frac{\text { amount of dye in standard }(\mathrm{mmol})}{\text { mean value for concentration readings of standard }(\mathrm{mmol})}
$$

Then: dye bound to sample $(\mathrm{mmol} / \mathrm{kg})=$

$\frac{\text { reagent blank concentration (mmol)-concentration of filtrate }(\mathrm{mmol})}{\text { dilution factor }} \times \frac{1000}{\text { sample weight }(\mathrm{g})}$

For DBC, the dilution factor was $1000 / 42$.

Determination of dye-bound-after-propionylation (DBAP) value. LPC samples (0.17$0.13 \mathrm{~g})$ were weighed into $100 \mathrm{ml}$ polyethylene bottles and three glass beads and $2 \mathrm{ml}$ 2.2 M-sodium acetate added to each as described previously. Propionic anhydride $(0.2 \mathrm{ml})$ was added, with gentle mixing to avoid unnecessary coating of the sides of the container, and the reaction mixture left standing $\mathrm{I} 6-24 \mathrm{~h}$ at room temperature. Foss FHI-I dyebuffer reagent $(40 \mathrm{ml})$ was added and the procedure described for $\mathrm{DBC}$ followed. The reagent blank, which contained $40 \mathrm{ml}$ Foss FHI-I dye-buffer reagent, $2 \mathrm{ml} 2 \cdot 2 \mathrm{M}$-sodium acetate and $0.2 \mathrm{ml}$ propionic anhydride, was mixed well and diluted $\mathrm{I}: \mathrm{I}(\mathrm{v} / \mathrm{v})$ with water, 
as for DBC. Values were calculated as for DBC, but using a dilution factor of $1000 / \mathbf{4 2} \cdot \mathbf{2}$.

$D B L$ value. This was calculated using the molecular weight of the lysine residue:

$$
\text { Reactive lysine }(\mathrm{g} / \mathrm{kg} \text { protein })=\frac{(\mathrm{DBC}-\mathrm{DBAP}) \times \mathrm{I} 28 \cdot \mathrm{I} 7}{\mathrm{I000}} \times \frac{1000}{\text { protein content }(\mathrm{g} / \mathrm{kg})}
$$

where protein content was uncorrected for moisture and is defined below.

Protein content. In this work protein was defined as $\mathrm{N}$ precipitated by tungstic acid $\times 6 \cdot 25$. Samples of LPC $(0.25-0.32 \mathrm{~g})$ were weighed into polyethylene bottles (100 ml), $19.6 \mathrm{ml}$ distilled water were added to each and the mixture shaken. $0.2 \mathrm{ml}$ sulphuric acid (IO0 $\mathrm{ml} / \mathrm{l}$ ) was then added, with shaking, followed by $0.2 \mathrm{ml}$ sodium tungstate solution ( $20 \mathrm{~g} / \mathrm{l}$ ). Shaking was continued at room temperature for $30 \mathrm{~min}$. The mixture was filtered (Whatman no. 54I) and the bottle rinsed with $30 \mathrm{ml}$ freshly prepared tungstic acid (containing $(/ \mathrm{l})$ $\mathrm{I} \cdot 2 \mathrm{~g}$ sodium tungstate and $\mathrm{I} \mathrm{ml}$ sulphuric acid). The precipitated protein was washed twice with $30 \mathrm{ml}$ tungstic acid, and the well-drained residue and filter paper were placed in a $250 \mathrm{ml} \mathrm{Kjeldahl} \mathrm{tube} \mathrm{with} \mathrm{three} \mathrm{Kjeltabs} \mathrm{S}$ (containing $5 \mathrm{mg}$ selenium and $5 \mathrm{~g}$ potassium sulphate each, supplied by Thomason and Capper Ltd, Runcorn, Cheshire WA7 INU), $20 \mathrm{ml}$ sulphuric acid and $0.5 \mathrm{ml}$ dodecanoic acid (saturated solution in ethanol) as an antifoaming agent (Marshall \& Walker, 1978). Hydrogen peroxide (100 vol.; $20 \mathrm{ml}$ ) was added carefully to each flask in a fume cupboard, small volumes at a time. The tubes were placed for $45 \mathrm{~min}$ in a preheated aluminium block maintained at $370^{\circ}$. Duplicate blanks were prepared containing reagent plus filter paper. After digestion the tubes were allowed to cool to room temperature and each was made up to $250 \mathrm{ml}$ with distilled water. The ammonia content was determined using the nitroprusside-salicylate-hypochlorite reagent system (Technicon Instrument Co. Ltd, 1974), with an AutoAnalyzer (Technicon Instruments Co. Ltd, Hamilton Close, Basingstoke, Hampshire RG2I 2 YE). Results were adjusted for reagent blanks.

Determination of total lysine by amino acid analysis. This was carried out according to the method of Spackman et al. (1958). LPC (0.008-0.012 g) was weighed into the extended, sealed-off limb of a right-angle, two-limb, Rotaflow stopcock (Corning Ltd, Stone, Staffordshire STI5 oBG) and $3 \mathrm{ml} 6 \mathrm{M}$-hydrochloric acid added. $\mathrm{N}_{2}$ was bubbled through the mixture for $20 \mathrm{~min}$ and the tube was sealed and heated in an oven at $\mathrm{I} 10^{\circ} \pm \mathrm{I}^{\circ}$ for $24 \mathrm{~h}$. The contents of the tube were quantitatively transferred to a round-bottomed flask and acid was removed under reduced pressure. Citric acid buffer, $\mathrm{pH} 2 \cdot 2(25 \mathrm{ml})$ was added and the flask was stoppered and shaken. The solution was filtered (Whatman no. I) to remove humin. At this stage, if necessary, the hydrolysate was stored at $-25^{\circ}$.

The amino acids were separated by ion-exchange chromatography, using a Jeol JLC-6AH automatic amino acid analyser (Jeol (UK) Ltd, Jeol House, Grove Park, Colindale, London NW9 oJN). Sample hydrolysates were compared with a standard amino acid solution; stock solution at $2.5 \mu \mathrm{m} / \mathrm{ml}$ (Pierce and Warriner (UK) Ltd, 44 Upper Northgate Street, Chester, Cheshire $\mathrm{CH}_{\mathrm{I}}{ }_{4} \mathrm{EF}$ ), working solution at $0.1 \mu \mathrm{m} / \mathrm{ml}$ (stock diluted with citric acid buffer).

Total lysine content was calculated as follows. The recovered residue weights of all the amino acids determined (including ammonia and using an estimated value for tryptophan) were added together and each residue expressed in $\mathrm{g} / \mathrm{kg}$ of this total. The tryptophan value used was based on the value of Byers ( $197 \mathrm{I} b$ ), i.e. that the weight of tryptophan in an LPC sample is approximately 0.2 of the weight of aspartic acid. That this value was of the right order was substantiated by analysis of fescue I (Festuca arundinacea L. var. Alta) LPC (see Table I). This had a tryptophan content of $23 \mathrm{~g} / \mathrm{kg}$ protein (mean of triplicate analyses) after alkaline hydrolysis and separation by ion-exchange chromatography (using the method 


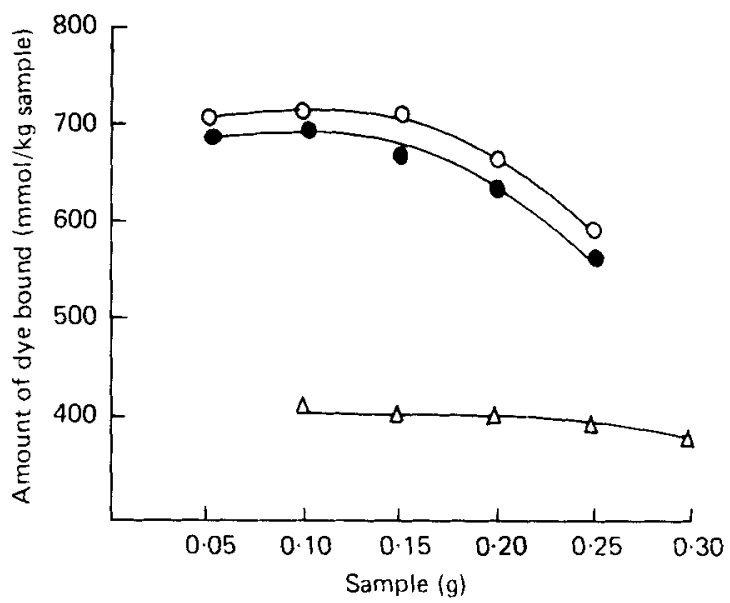

Fig. I. The effect of sample weight (g) on the amount of dye bound ( $\mathrm{mmol} / \mathrm{kg} \mathrm{sample}$ ) at $\mathrm{I} 6 \mathrm{~h}$ and $25^{\circ}$ using lucerne (Medicago sativa L.) sample no. Io (see Table i) leaf-protein concentrate, before and after propionylation (for details of procedures, see p. 447). All points represent the mean of duplicate analyses, uncorrected for moisture content. (O), Foss FHI-I dye-buffer reagent only; (๑), Foss FHI-I dye-buffer reagent with sodium acetate; $(\Delta)$, Foss FHI-I dye-buffer reagent after propionylation.

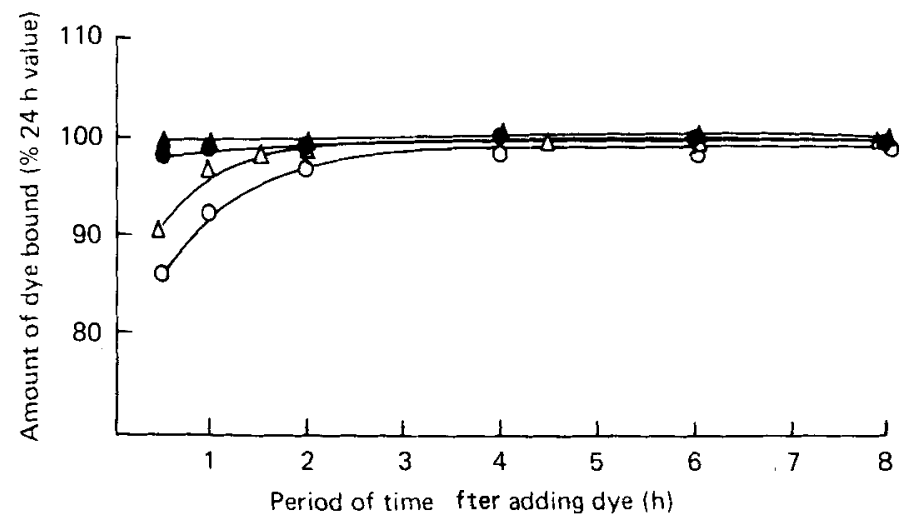

Fig. 2. Relation between the amount of dye bound ( $\% 24 \mathrm{~h}$ value) at $25^{\circ}$ by four leaf-protein concentrate (LPC) samples and the period of time after adding the dye (h), in the absence of sodium acetate (for details of procedures, see p. 447). All points represent the mean of duplicate analyses, uncorrected for moisture content. (O), Lucerne (Medicago sativa L.) sample no. IO; (O), lucerne sample no. $2 ;(\triangle)$, lucerne sample no. $8 ;(\Delta)$, fescue (Festuca arundinacea L. var. Alta) sample no. 2. For details of LPC samples, see Table I.

of Hugli \& Moore, 1972), and an aspartic acid content of $98 \cdot 5 \mathrm{~g} / \mathrm{kg}$ protein (mean of duplicate analyses of acid hydrolysates).

\section{RESULTS AND DISCUSSION}

Some of the problems associated with the interpretation of $\mathrm{DBC}$ arise from a failure to appreciate that the extent of the dye-protein interaction is dependent on the experimental conditions (Lakin, 1978). Accordingly, in order to ensure reproducible results, rigid standardization of experimental procedures is essential; with the DBC method this is even more 


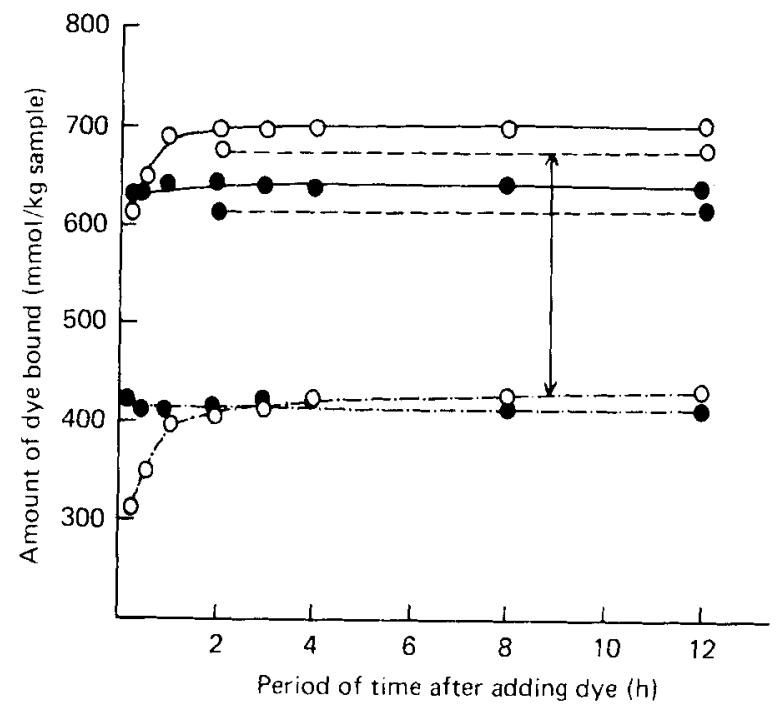

Fig. 3. The relationship between the amount of dye bound ( $\mathrm{mmol} / \mathrm{kg} \mathrm{sample)}$ at $25^{\circ}$ by lucerne (Medicago sativa L.) sample no. 10 (see Table I) leaf-protein concentrate (LPC) (O) and lucerne LPC sample no. $2(\bullet)$, before and after propionylation, and the period of time after adding the dye (h) (for details of procedures, see p. 447). (- —_- Dye-binding capacity (mmol/kg sample) before propionylation in the absence of sodium acetate; $(----)$, dye-binding capacity $(\mathrm{mmol} / \mathrm{kg}$ sample) before propionylation in the presence of sodium acetate; $(\cdot--\cdot-\cdot)$, dye bound (mmol $/ \mathrm{kg}$ sample) after propionylation; $\longleftrightarrow$ dye bound $(\mathrm{mmol} / \mathrm{kg}$ sample) due to reactive lysine for lucerne sample no. 10. All points represent the mean of duplicate analyses uncorrected for moisture content.

necessary, as the difference between two dye-binding determinations is involved. Furthermore, food materials may not all behave in a similar manner with respect to the Foss FHI-I dye-buffer reagent as does the LPC described here, so that for each type of food the correct experimental conditions must be established before the method is accepted for it.

The effect of sample weight on the DBC and DBAP values was studied using lucerne (Medicago sativa L.) LPC (Fig. I); the effect of 2.2 M-sodium acetate on the DBC was also investigated, as this reagent is necessary for propionylation. As the amount of $\mathrm{CI}$ Acid Orange $\mathrm{I} 2$ bound from the Foss dye-buffer reagent was independent of sample weight from 0.05 to $0.15 \mathrm{~g}$, weights of $0.08-0.12 \mathrm{~g}$ were used for direct measurement of DBC, but $0.13-0.17 \mathrm{~g}$ were used when the sample was to be propionylated.

The dye uptake by four LPC samples (three lucerne preparations and one fescue preparation) as a function of the interval elapsed after addition of the dye was investigated (Fig. 2). These curves indicate that the rate of dye uptake varies with LPC samples, but for all samples uptake reached at least $98 \%$ by $8 \mathrm{~h}$ and $100 \%$ by $\mathrm{I} 6 \mathrm{~h}$ of that at $24 \mathrm{~h}$. For the purposes of the present work, $16 \mathrm{~h}$ was chosen in view of the convenience of 'overnight' shaking.

Fig. 3 shows the dye uptake by two lucerne LPC samples in the presence of $2 \mathrm{ml} 2 \cdot 2$ M-sodium acetate (using $0.08-0.12 \mathrm{~g}$ ), as a function of the interval elapsed after addition of the dye, at 4 and $24 \mathrm{~h}$. Values for these two samples from Fig. 2 are also given in Fig. I for comparison. Fig. 3 also shows the dye uptake after propionylation for these two LPC samples. The curves before and after propionylation follow the same pattern. There is a decrease in the total dye bound in the presence of $2.2 \mathrm{M}$-sodium acetate. This effect was evident in Fig. I and may have been related to the change of the pH of the Foss FHI-I 


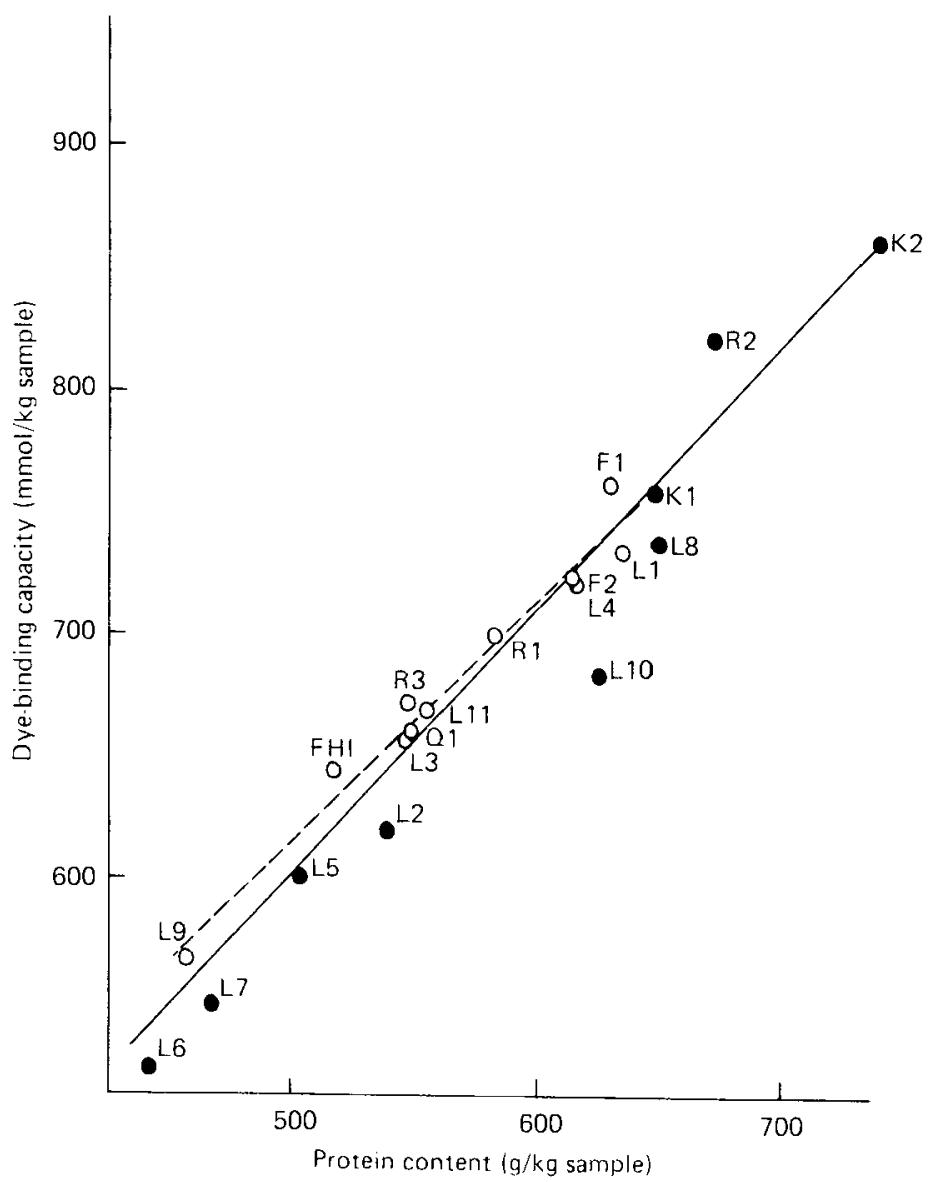

Fig. 4. Relationship between dye-binding capacity (mmol/kg sample) and protein content (tungsticacid-precipitated nitrogen $\times 6.25)(\mathrm{g} / \mathrm{kg}$ sample) for various leaf-protein concentrate samples. All points represent the mean of duplicate analyses, uncorrected for moisture content. (O), Samples in which dye-binding lysine and total lysine (for details, see Table 2) values are within $10 \mathrm{~g} / \mathrm{kg}$ protein; ( ), samples in which lysine values differ by more than $10 \mathrm{~g} / \mathrm{kg}$ protein; (sion line for all samples; ( --$)$, regression line for samples in which lysine values are within $10 \mathrm{~g} / \mathrm{kg}$ protein. F, fescue (Festuca arundinacea L. var. Alta); FH, fat hen (Chenopodium album L.); K, kale (Brassica oleracea L.) L, lucerne (Medicago sativa L.); Q, quinoa (Chenopodium quinoa L.); R, ryegrass (Italian) (Lolium multiflorum L. var. RVP). For further details of samples, sce Table 1 .

dye-buffer reagent on the addition of sodium acetate (from $\mathrm{pH} \mathrm{I} \cdot 6$ to $\mathrm{pH} 2 \cdot 2$ ). The difference in dye uptake due to propionylation of lysine is indicated in Fig. 3 for lucerne sample no. 10.

Fig. 4 shows the relationship between DBC (in the presence of sodium acetate) and protein content (tungstic-acid-precipitated $N \times 6.25$ ) for the twenty LPC samples studied. The standard error for the dye-binding method was $\mathrm{I} \cdot 2 \mathrm{I}(n \mathrm{n} 20)$ and for protein, by Kjeldahl digestion, $1.33(n 20)$, the correlation $(r)$ between the two methods being 0.97 . In most experimental work, e.g. feeding experiments, crude protein values (total $\mathrm{N}$ by Kjeldahl $\times$ 6.25 ) are usually quoted. Where non-protein- $N$ values are high, the error this introduces can be considerable (Lakin, 1978). With LPC most of the non-protein-N has been washed out, but the extent of washing varies with some of the LPC preparations studied, as they 


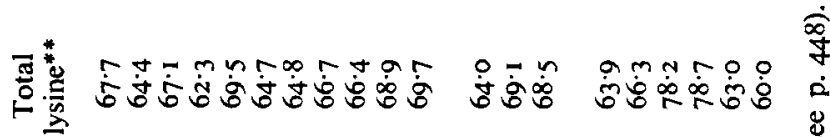
$\stackrel{8}{8}$

竞

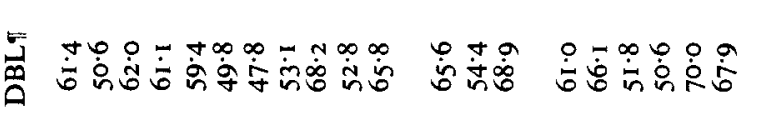

咢安

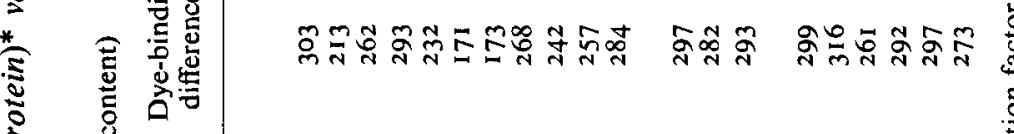

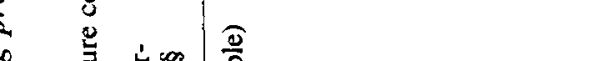

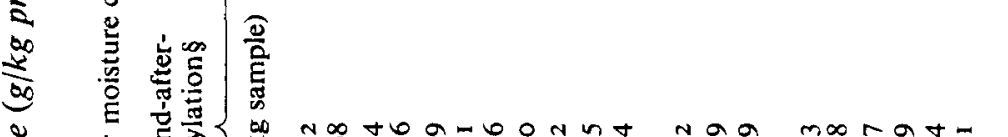

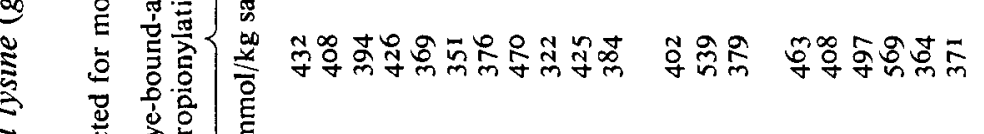

ฐ

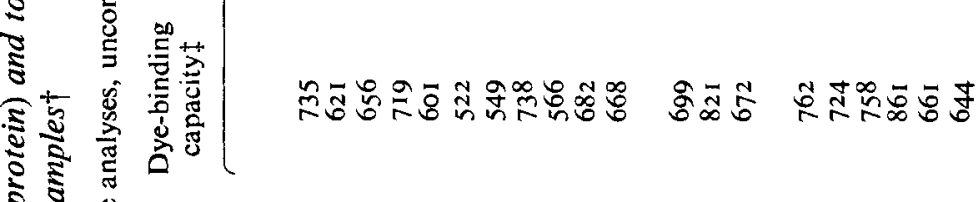

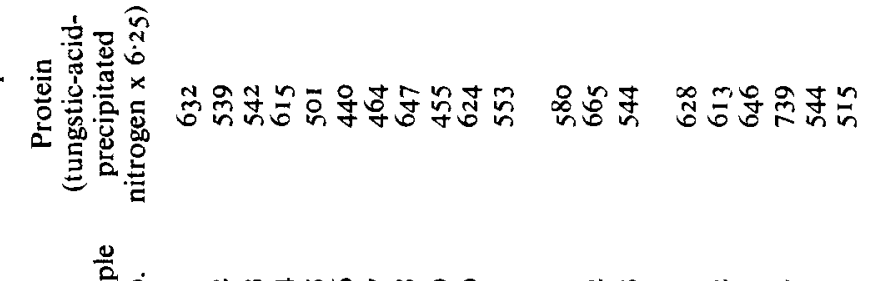

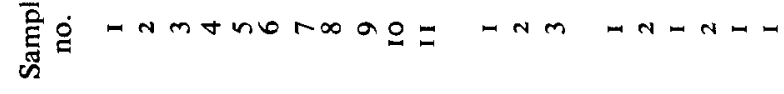

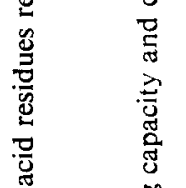


were not all prepared in this laboratory. This may have led to some variability in nonprotein-N, though this variation may not be as significant with LPC samples as with some foodstuffs.

Table 2 compares the reactive lysine determined by dye-binding for the twenty LPC samples with their total lysine content. Those samples in which DBL and total lysine values differed by more than Io $\mathrm{g}$ lysine/ $\mathrm{kg}$ protein are below the other values (Fig. 4 ), which is to be expected because loss of reactive lysine would reduce the DBC. There was one exception, that of ryegrass sample no. 2 LPC, for which there is no simple explanation. If the values of those samples differing by more than $10 \mathrm{~g}$ lysine $/ \mathrm{kg}$ protein are excluded from the regression analysis, there was a marginal improvement of the correlation coefficient $(r 0.98)$ and the slope of the line changed (Fig. 4).

If the results in Table $I$ are examined in conjunction with Fig. 4, it is seen that LPC lucerne samples nos. 7,8,9 and $\mathrm{I} 0$, which might be expected to have a reduced available lysine content because of poorer processing conditions, exhibit a difference between DBL and total lysine $>10 \mathrm{~g} / \mathrm{kg}$ protein. LPC lucerne samples nos. 2 and 5 , ryegrass (Lolium multiflorum L. var. RVP) sample no. 2 and kale (Brassica oleracea L.) sample no. I would not have been expected to show such large differences, as all these samples were freezedried, and this may indicate that rapid reactions between phenols and reactive lysine are occurring in the extracted juice. According to Hurrell \& Carpenter (I975), DBC does not indicate early Maillard damage (although the mechanism for propionylation followed by dye-binding has not been fully elucidated) and, because conditions of processing were not severe enough for late Maillard damage to occur, phenol-protein interaction seems the more likely explanation. In the instance of lucerne LPC sample no. 7, heating to $95^{\circ}$ for coagulum precipitation may account for the loss of reactive lysine, as lucerne sample no. 3 LPC, which was produced by steam-injection (to $85^{\circ}$ ) coagulation from the same batch of juice, did not show significant loss of reactive lysine.

Grateful acknowledgement is made to the Wolfson Foundation for financial assistance, to Dr C. Humphries and Mr J. Dick for help in the preparation of samples, to Messrs $\mathrm{N}$. Ward, K. Westcott and S. Wilkinson of the Department of Agriculture, University of Reading, for the extraction of leaf juice, to $\mathrm{Mr} \mathrm{R}$. Mead for advice on statistical analysis, to $\operatorname{Dr}$ A. Zand-Moghaddam for advice on amino acid analysis and for the tryptophan determination and to Dr A. L. Lakin for helpful discussions.

\section{REFERENCES}

Allison, R. M., Laird, W. M. \& Synge, R. L. M. (1973). Br. J. Nutr. 29, 51.

Byers, M. (197I a). J. Sci. Fd Agric. 22, 242.

Byers, M. (I971 b). In Leaf Protein: its Agronomy, Preparation, Quality and Use, IBP Handbook no. 20, p. 95 [N. W. Pirie, editor]. Oxford: Blackwell Scientific Publications Ltd.

Carpenter, K. J. (1974). In Nutrients in Processed Foods - Proteins, p. 99 [P. L. White and D. C. Fletcher, editors]. Acton, Massachusetts: Publishing Sciences Group Inc.

Carpenter, K. J. \& Booth, V. H. (1973). Nutr. Abst. Rev. 43, 424.

Davys, M. N. G. \& Pirie, N. W. (1960). Engineering 190, 274.

Davys, M. N. G. \& Pirie, N. W. (1965). J. agric. Engng Res. ro, 142.

Davys, M. N. G. \& Pirie, N. W. (I969a). Biotech. Bioeng II, 517.

Davys, M. N. G. \& Pirie, N. W. (1969b). Biotech. Bioeng 11, 529.

Gerloff, E. D., Lima, I. H. \& Stahman, M. A. (1965). J. agric. Fd Chem. r3, 139.

Hugli, T. E. \& Moore, S. (I972). J. biol. Chem. 247, 2828.

Hurrell, R. F. \& Carpenter, K. J. (1975). Br. J. Nutr. 33, 101.

Hurrell, R. F. \& Carpenter, K. J. (1976). Proc. Nutr. Soc. 35, 23A.

Jones, G. P. (I974). The use of dye-binding procedures for the evaluation of protein quality. PhD thesis, University of Reading.

Lakin, A. L. (1973). In Proteins in Human Nutrition, p. 179 [J. W. G. Porter and B. A. Rolls, editors]. London and New York: Academic Press. 
Lakin, A. L. (1978). In Developments in Food Analysis Techniques, vol. I, p. 43 [R. D. King, editor]. Barking, Essex: Applied Science Publishers Ltd.

Marshall, C. M. \& Walker, A. F. (1978). J. Sci. Fd. Agric. 29, 940.

Pierpoint, W. S. (1969a). Biochem. J. 112, 609.

Pierpoint, W. S. (1969b). Biochem. J. 112, 619.

Sandler, L. \& Warren, F. L. (1974). Analyt. Chem. 46, 1870.

Spackman, D. H., Stein, W. H. \& Moore, S. (I958). Analyt. Chem. 30, I 190.

Technicon Instrument Co. Ltd (1974). Industrial Method no. 23r-74A. Geneva: Technicon International. Wilsdon, G. C. H. (1977). In Green Crop Fractionation, p. I 55 [R. J. Wilkins, editor]. Hurley, Berkshire: British Grassland Society. 